\title{
Morphological Characteristics of Soft Tissue Profile of Angle's Class II Division I Malocclusion before and after Orthodontic Treatment
}

\author{
Características Morfológicas del Perfil de Tejido Blando de la Clase II de la División I \\ de Maloclusión de Ángulo Antes y Después del Tratamiento de Ortodoncia
}

Jing Xuan ${ }^{1}$; Li Bing ${ }^{1}$; Shi-Feng Li $^{2}$; Yan-Ning Ma ${ }^{1}$; Tae-Geon Kwon ${ }^{2} \&$ Xiu-Ping Wu ${ }^{1}$

XUAN, J.; BING, L.; LI, S. F.; MA, Y. M.; KWON, T. G. \& WU, X. P. Morphological characteristics of soft tissue profile of angle's class II division 1 malocclusion before and after orthodontic treatment. Int. J. Morphol., 36(1):26-30, 2018.

SUMMARY: By analysing cephalometrics before and after the treatment of Angle's class II division 1 malocclusion, soft tissue profile changes were observed, and to explore whether there was a correlation between the change of posterior occlusal plane (OP-P) and soft tissue profile. The study aimed to provide a theoretical reference in the clinical diagnosis and orthodontic treatment of early permanent dentition of Angle class II division 1 malocclusion patients. We randomly selected 20 cases of orthodontics in Shanxi Medical University orthodontics patients (aged 12-18 years) of the lateral cephalograms, Winceph 8.0 software was used to measure the posterior occlusal plane (OP-P), TUL-EP, TLL-EP, nasolabial angle, upper lip base thickness, upper lip tension, lower lip H line distance, chin soft tissue thickness and Z angle. And SPSS 22.0 software was used to analyze the correlation between OP-P and other measurement indexes. The change of posterior occlusal plane was positively related to the distance from upper lip to the esthetic plane, the distance from lower lip to the esthetic plane, the tension of the upper lip and distance from lower lip to $\mathrm{H}$ line, and the change of posterior occlusal plane was negatively related to nasolabial angle and $\mathrm{Z}$ angle. The change of posterior occlusal plane had no significant correlation with upper lip base thickness and soft tissue chin thickness. The change of posterior occlusal plane has an important guiding significance for orthodontic treatment,by focusing on the change of the posterior occlusal plane to achieve the purpose of changing the soft tissue profile.

KEY WORDS: Morphological characteristics; Class II division 1 malocclusion; Posterior occlusal plane; Cephalometric measurements; Soft tissue profile.

\section{INTRODUCTION}

Maxillar and anterior teeth protrusion, deep overbite, mandibular grows with clockwise rotation, incompetent growth of lip, poor morphology of chin and other poor coordinated surface types are clinical manifestations with Angle class II division 1 malocclusion patients (Cabrita et al., 2017; Mehta et al., 2017; Ozbilek et al., 2017). These performances affect patients' confidence, mental health and daily communication. With the improvement of orthodontic technology, orthodontists and patients are no longer satisfied with teeth, but pay more attention to the facial coordination and appearance. Because of the great variability of soft tissue, how to use orthodontic treatment to change soft tissue with a certain extent is always a problem which confuses orthodontists. Successful orthodontic treatment is not only to establish a balanced, stable and beautiful occlusal relationship, but also to achieve coordinated soft tissue profile and appearance. The posterior occlusal plane is a very important guiding to diagnosis and analysis of malocclusion according to some researches (Kamal et al., 2016; Shishkin et al., 2016). The previous research was mainly based on teeth, maxillofacial soft and hard tissue and different types of profile before and after treatment, but did not realize the importance of posterior occlusal plane. In this study, by measuring the change of posterior occlusal plane and soft tissue profile indexes before and after treatment, the writer tried to explore the correlation between posterior occlusal plane and soft tissue profile, so as to reveal the importance of them (Basciftci et al., 2004; Kook et al., 2016).

\footnotetext{
${ }^{1}$ Stomatology Hospital, Shanxi Medical University, Taiyuan, China.

${ }^{2}$ School of Dentistry, Kyungpook National University, Daegu, Korea.

Funding: Shanxi Province International Science and Technology Cooperation Project(China-Korea), No.2015081030; Shanxi Province returned overseas students research funding projects, No.2015-053.
} 


\section{MATERIAL AND METHOD}

Materials selection. Twenty patients aged 20-18 years with an average age of 14.3 years were selected from 2015 to 2017 years in orthodontics, Shanxi Medical University Stomatological Hospital. They were all Skeletal Class I, had distal molars relationship and complete set of dentition. After

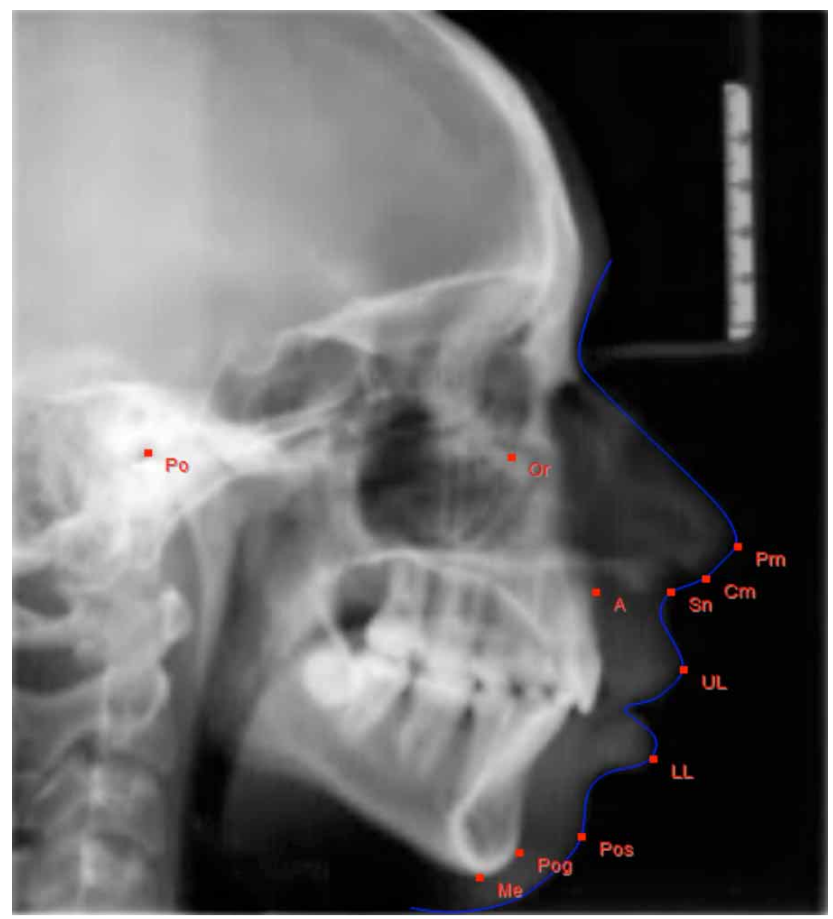

Fig. 1. Index points of measurement in cephalometric radiographs straight wire fixed appliance treatment, the patients basically reached the neutral molars relationship, normal overjet and overbite.

Experimental method. Twenty patients were treated with the same projection conditions before the treatment of the anteroposterior $\mathrm{X}$-ray radiographs, and the same person in a continuous of centric occlusion, the use of Winceph 8.0 software for cephalometric analysis of fixed-point, left and right sides do not overlap when the two points to take two points.

Index points of measurement. Po: Porion; Or: Orbitale; Prn: Pronasale; Cm: Columella; Sn: Subnasale; A:Subspinale; UL: Upper labrale; LL: Lower labrale; Pos: Pogonion of soft tissue; Pog: Pogonion; Me: Menton (Fig. 1).

Measurement index of hard tissue Posterior occlusal plane (OP-P):cusp of maxillary second premolar to middle point of maxillary second molar.

Measurement indexes of soft tissue. (1) Distance of TULEP; (2) Distance of TLL-EP; (3) Nasolabial angle; (4) Upper lip base thickness ( $3 \mathrm{~mm}$ below A to $\mathrm{Sn}$ ); (5) Tension of the upper lip (labial surface of upper incisor to UL); (6) Distance of lower lip to $\mathrm{H}$ line; (7) Soft tissue chin thickness (distance from Pos and Pog to MP plane); (8) Z angle (Fig. 2).

Statistical Process. Experiments were performed by SPSS 22.0 software to analyze whether there was correlation between changes of posterior occlusal plane and changes in soft tissue profile before and after orthodontic treatment.

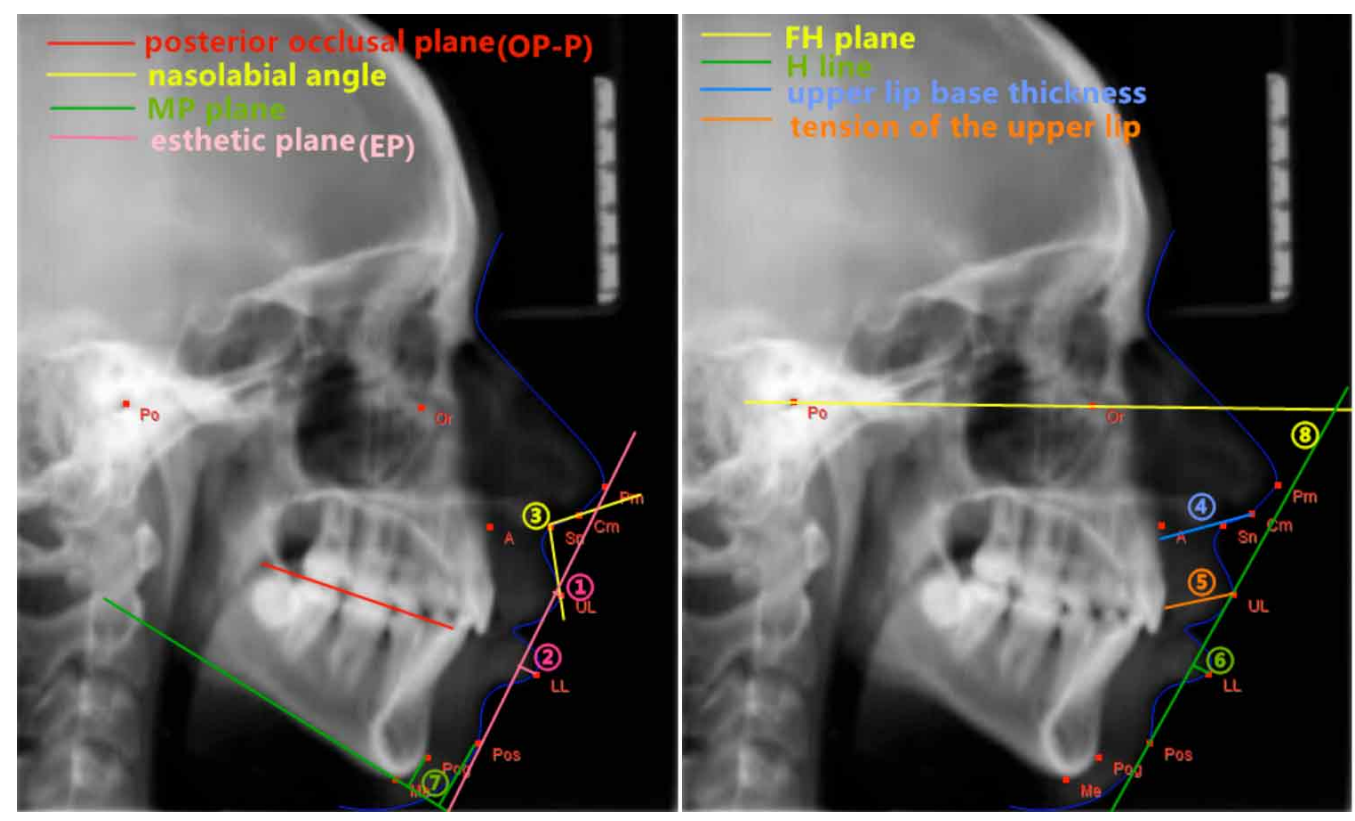

Fig.2 .Measurement indexes in cephalometric radiographs 


\section{RESULTS}

After 20 adolescent patients taken orthodontic treatment, the change of distance from upper lip to esthetic plane had a positive correlation with posterior occlusal plane $(r=0.365)$, distance from lower lip to esthetic plane was positively related to posterior occlusal plane $(\mathrm{r}=0.278)$, the plane was negatively correlated with nasolabial angle ( $\mathrm{r}=-$
0.742), the upper lip tension had a positive correlation with the plane $(\mathrm{r}=0.419)$, distance from lower lip to $\mathrm{H}$ line was positively correlated ( $\mathrm{r}=0.108)$, upper lip base thickness, chin soft tissue thickness and the plane had no correlation, $\mathrm{Z}$ angle was negatively correlated with the posterior occlusal plane (Table I).

Typical cases. Changes of facial and lateral radiographs before and after treatment of typical cases (Fig. 3A and 3B).

Table I. Correlative analysis of change of posterior occlusal plane and soft tissue profile indexes after treatment

\begin{tabular}{lccc}
\hline Measurement indexes & $\begin{array}{c}\text { Changes before and after } \\
\text { Orthodontic treatment } \\
(\mathrm{x} \pm \mathrm{s})\end{array}$ & $\mathrm{r}$ & $\mathrm{p}$ \\
\hline TUL-EP $(\mathrm{l} / \mathrm{mm})$ & $2.134 \pm 2.035$ & 0.365 & $<0.01$ \\
TLL-EP $(\mathrm{l} / \mathrm{mm})$ & $3.013 \pm 3.840$ & 0.278 & $<0.01$ \\
Nasolabial angle $\left({ }^{\circ}\right)$ & $-0.629 \pm 4.652$ & -0.742 & $<0.01$ \\
Upper lip base thickness $(1 / \mathrm{mm})$ & $1.782 \pm 2.219$ & 0.694 & $>0.05$ \\
Tension of the upper lip $(1 / \mathrm{mm})$ & $0.127 \pm 1.754$ & 0.419 & $<0.05$ \\
Lower lip-H line distance $(1 / \mathrm{mm})$ & $0.511 \pm 0.930$ & 0.108 & $<0.05$ \\
Soft tissue chin thickness $(1 / \mathrm{mm})$ & $-0.523 \pm 1.661$ & 0.811 & $>0.05$ \\
$\mathrm{Z}$ angle $\left(\mathrm{I}^{\circ}\right)$ & $-1.102 \pm 5.324$ & -0.572 & $<0.05$ \\
\hline
\end{tabular}
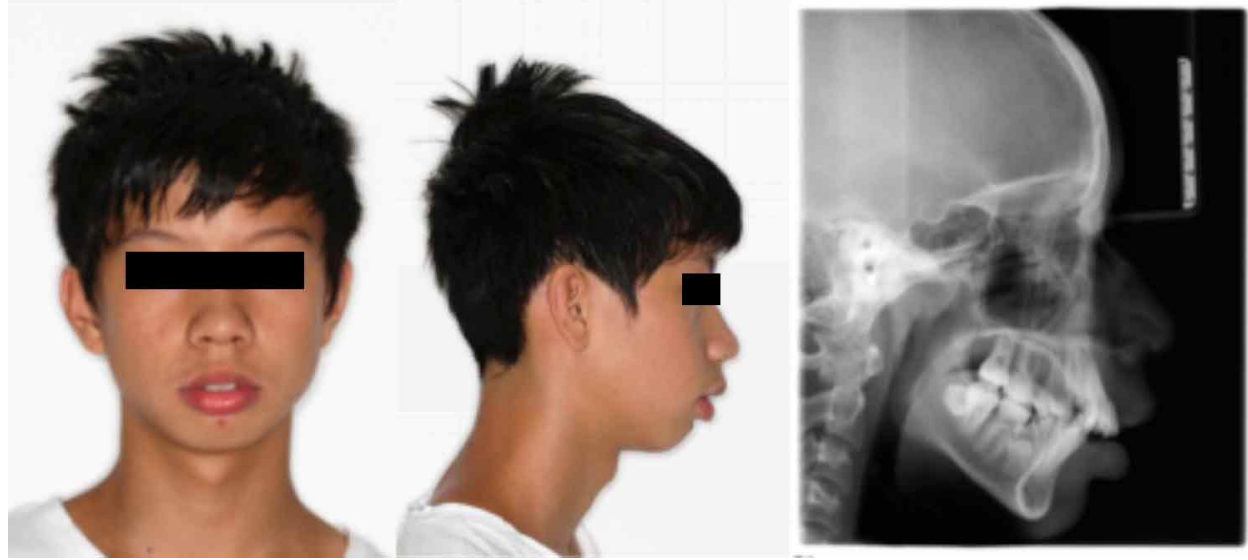

Fig.3A. Class II 1 malocclusion patient before treatment.
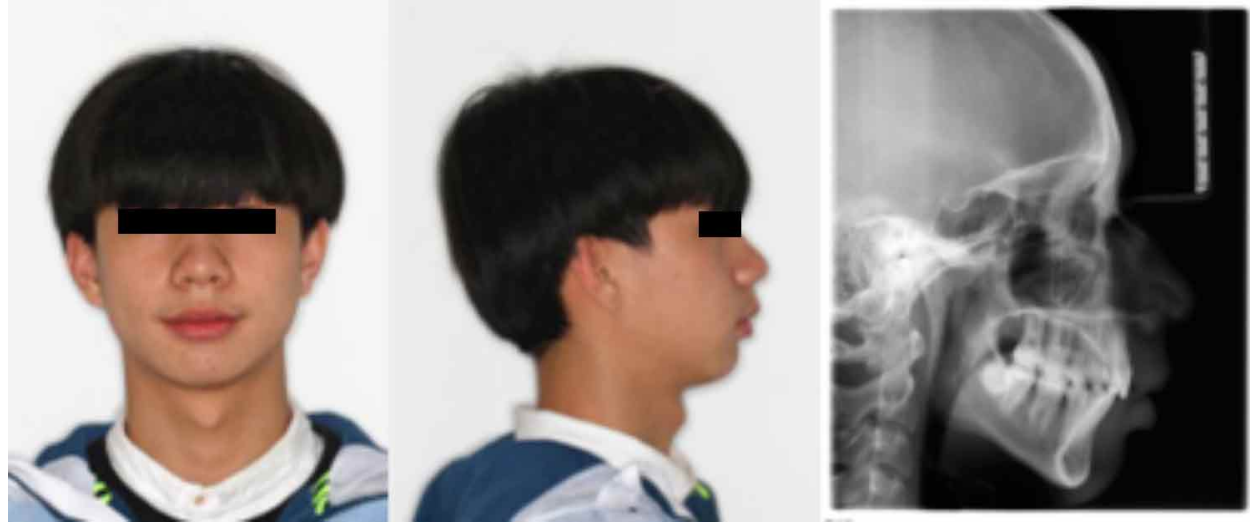

Fig.3B. Class II 1 malocclusion patient after treatment. 


\section{DISCUSSION}

In orthodontic treatment, changing the occlusal state of the patient is the first goal pursued by each orthodontist, and for the patient, it seems more attention to the change in facial profile. The characteristics of class II malocclusion patients are usually a protrusion of basifacial 1/3 part and upper lip, incompetent growth of lip, poor morphology of chin and small nasolabial angle, which are often chief complaints of patients (Halimi et al., 2011; Gandhi et al., 2017). In recent years, more and more scholars pay attention to the importance of occlusal plane, which is a main reference indication in diagnosis and treatment of malocclusion. The inclination of occlusal plane, especially posterior occlusal plane has important effects on establishment of the position and growth of mandibular (Hajeer, 2014; Kanuru et al., 2017). It should pay more attention to controlling occlusal plane in orthodontic treatment. Effective controlling and adjusting the occlusal plane can avoid the unfavorable mandibular rotation and achieve a good facial profile. Through changing the position of occlusion can achieve satisfactory and therapeutic effect. The indexes in this study are concentrated on the relationship between the change of posterior occlusal plane and nose, lip and chin.

Lip changes. After orthodontic treatment, Class II malocclusion patients' upper lip protrusion was obvious, but the upper lip thickness changed little. The protrusion and position of the upper lip reflected the extent of maxillar protrusion. Therefore, in clinical work, distance from upper lip to esthetic plane should be considered as characterized evaluation index for class II malocclusion in clinical work. $\mathrm{Z}$ angle decreased obviously, lower lip to aesthetic plane and lower lip thickness increased. So the lower lip is compensated for the soft tissue and can disguise the skeletal retraction of mandibular (Yogosawa, 1990). The inclination of posterior occlusal plane of class II malocclusion patients decreased after orthodontic treatment. At the same time, the mandibular had ante displacement. Meanwhile, the obvious decrease of distance of upper lip to esthetic plane indicated that the upper lip retruded, the protrusion decreased and provided certain space when retracting anterior teeth of class II malocclusion (Chen \& Xie, 2010). The increase of tension of the upper lip after retracting anterior teeth indicated that the thickness of upper lip can partly compensate facial depression which closure space led when moving anterior teeth. The decrease of distance from lower lip to esthetic plane indicated that when upper anterior teeth retract, lower anterior teeth retracted too because they got off from the upper anterior teeth's barrier. But some researches have shown that there was negative correlation between the changes of SNB angle and posterior occlusal plane, which means that with the change of posterior occlusal plane, sagittal position of maxillar changes, and the lower lip protrusion will increase with anterior teeth erect.

Nasolabial angle changes. Nasolabial angle is on the side of the position of upper lip and nasal bottom, indicating the upper lip protrusion. Changing the inclination or position of anterior teeth can change the nasolabial angle in orthodontic treatment. In this study, with the anterior teeth retracting, the inclination of posterior occlusal plane decreased and nasolabial angle increased. Lo \& Hunter (1982) argues that the change of nasolabial angle is related to maxillary anterior teeth retraction in orthodontic treatment. Chinese scholars found that the relationship between extraction treatment and change of nasolabial angle is different in adolescents and adults. Nasolabial angle of adolescents has no significant change when adult's increases obviously (Song \& Wu, 2007; Wu et al., 2017), but there may be interference of growth and development. Therefore, although the study found that there was a correlation between the change of nasolabial angle and posterior occlusal plane with class II malocclusion patients, but in the other classifications, whether there is a relationship between them also requires further research.

Chin changes. Chin is considered to be the most important index of soft tissue profile in the evaluation standard. Class II classification patients have obvious mandibular retrusion and chin is obvious retrusion relatived to the nasal root. Tense of chin muscle also destroyed esthetic of facial profile (Song \& Wu; Shishkin et al.; Wu et al.). In this study, $\mathrm{Z}$ angle decreased with increase of inclination of posterior occlusal plane,but studies had shown that many factors infected retraction of upper lip, such as soft tissue structures of lip. Further research is needed to find these factors. Research also shown that many cases had no obvious improvement of soft tissue chin at a later stage of development, only through orthodontic treatment. So for patients with chin deficiency, they may elect genioplasty surgery after 18 years of age. Then the soft tissue profile can be more perfect (Kim et al., 2017; Rego et al., 2017).

The change of the posterior occlusal plane has important guiding significance for orthodontic treatment, through the change of the occlusal plane to achieve the purpose of changing the soft tissue profile. 
XUAN, J.; BING, L.; LI, S. F.; MA, Y. M.; KWON, T. G. \& WU, X. P. Características morfológicas del perfil de tejido blando de la clase ii de la división i de maloclusión de angulo antes y después del tratamiento de ortodoncia. Int. J. Morphol., 36(1):26-30, 2018.

RESUMEN: Se realizó un estudio cefalométrico antes y después del tratamiento de ortodoncia en pacientes portadores de maloclusión clase II división 1 de Angle. Se observaron cambios en el perfil de los tejidos blandos y se exploró si había una correlación entre el cambio del plano oclusal posterior (OP-P) y el perfil de los tejidos blandos. El objetivo de este estudio fue otorgar una referencia teórica en el diagnóstico clínico y el tratamiento de ortodoncia de los pacientes con dentición permanente temprana con maloclusión clase II división 1 de Angle. Seleccionamos al azar 20 casos cefalometrías de pacientes de ortodoncia de la Universidad Médica de Shanxi (entre 12 y 18 años). Para ello, se utilizó el software Winceph 8.0 para medir el plano oclusal posterior (OP-P), TUL-EP, TLL-EP, ángulo nasolabial, grosor de la base del labio superior, tensión del labio superior, distancia entre líneas del labio inferior $\mathrm{H}$, grosor del tejido blando del mentón y ángulo $\mathrm{Z}$. Se utilizó el software SPSS 22.0 para analizar la correlación entre OP-P y otros índices. El cambio del plano oclusal posterior tuvo una correlación positiva con la distancia desde el labio superior al plano estético, la distancia desde el labio inferior hasta el plano estético, la tensión del labio superior y distancia del labio inferior a la línea $\mathrm{H}$. El cambio del plano oclusal posterior tuvo una correlación negativa con el ángulo nasolabial y el ángulo Z. El cambio del plano oclusal posterior no tuvo una correlación significativa con el grosor de la base del labio superior y la barbilla de tejido blando. El cambio del plano oclusal posterior tiene un importante significado de orientación para el tratamiento de ortodoncia, de tal manera que al cambiar el plano oclusal posterior se podrá lograr el propósito de cambiar el perfil del tejido blando.

PALABRAS CLAVE: Características morfológicas; Maloclusión clase II división 1; Plano oclusal posterior; Mediciones cefalométricas; Perfil de tejidos blandos.

\section{REFERENCES}

Basciftci, F. A.; Uysal, T.; Buyukerkmen, A. \& Demir, A. The influence of extraction treatment on Holdaway soft-tissue measurements. Angle Orthod., 74(2):167-73, 2004.

Cabrita, J. P.; Bizarra, M. F. \& Graça, S. R. Prevalence of malocclusion in individuals with and without intellectual disability: A comparative study. Spec. Care Dentist, 37(4):181-6, 2017.

Chen, J. \& Xie, J. Z. Multivariate regression analysis of nasolabial angle of adult changes after orthodontic treatment. J. Mod. Stomatol., 24(5):337$8,2010$.

Gandhi, V.; Mehta, F. \& Joshi, H. Treatment of class II malocclusion and impacted canines with two-phase orthodontic treatment. Contemp. Clin. Dent., 8(1):161-6, 2017.

Hajeer, M. Y. Assessment of dental arches in patients with Class II division 1 and division 2 malocclusions using 3D digital models in a Syrian sample. Eur. J. Paediatr. Dent., 15(2):151-7, 2014.

Halimi, A.; Azeroual, M. F.; Abouqal, R. \& Zaoui, F. A comparative study of the transverse dimensions of the dental arches between Class I dental occlusion and Class II1 and Class II2 malocclusions.
Odontostomatol. Trop., 34(136):47-52, 2011.

Kamal, A. T.; Shaikh, A. \& Fida, M. Occlusal outcome of non-extraction and all first premolars extraction treatment in patients with class-I malocclusion. J. Ayub. Med. Coll. Abbottabad., 28(4):664-8, 2016.

Kanuru, R. K.; Bhasin, V.; Khatri, A.; Dodda, K. K.; Singh, E. \& Grover, S. Comparison of complications in removable mandibular acrylic splint and cantilever herbst for management of class II malocclusion: A retrospective study. J. Contemp. Dent. Pract., 18(5):363-5, 2017.

Kim, K.; Choi, S. H.; Choi, E. H.; Choi, Y. J.; Hwang, C. J. \& Cha, J. Y. Unpredictability of soft tissue changes after camouflage treatment of Class II division 1 malocclusion with maximum anterior retraction using miniscrews. Angle Orthod., 87(2):230-8, 2017.

Kook, Y. A.; Park, J. H.; Bayome, M.; Kim, S.; Han, E. \& Kim, C. H. Distalization of the mandibular dentition with a ramal plate for skeletal Class III malocclusion correction. Am. J. Orthod. Dentofacial Orthop., 150(2):364-77, 2016.

Lo, F. D. \& Hunter, W. S. Changes in nasolabial angle related to maxillary incisor retraction. Am. J. Orthod., 82(12):384-91, 1982.

Mehta, P.; Sagarkar, R. M. \& Mathew, S. Photographic Assessment of Cephalometric Measurements in Skeletal Class II Cases: A Comparative Study. J. Clin. Diagn. Res., 11(6):ZC60-4, 2017.

Ozbilek, S.; Gungor, A. Y. \& Celik, S. Effects of skeletally anchored Class II elastics: A pilot study and new approach for treating Class II malocclusion. Angle Orthod., 87(4):505-12, 2017.

Rego, M. V.; Martinez, E. F.; Coelho, R. M.; Leal, L. M. \& Thiesen, G. Perception of changes in soft-tissue profile after Herbst appliance treatment of Class II Division 1 malocclusion. Am. J. Orthod. Dentofacial Orthop., 151(3):559-64, 2017.

Shishkin, K. M.; Arsenina, O. I.; Shishkin, M. K. \& Popova, N. V. Stability of orthodontic correction: preconditions of relapses caused by occlusal forces. Stomatologiia (Mosk), 95(5):47-50, 2016.

Song, L. J. \& Wu, J. Cephalometric changes of the morphology of the symphysis after extraction in Angle Class II division 1 malocclusion patients. Shanghai Kou Qiang Yi Xue, 16(4):399-403, 2007.

Wu, X. P.; Xuan, J.; Liu, H. Y.; Xue, M. R. \& Bing, L. Morphological characteristics of the cranial base of early angle's Class II division 1 malocclusion in permanent teeth. Int. J. Morphol., 35(2):589-95, 2017.

Yogosawa, F. Predicting soft tissue profile changes concurrent with orthodontic treatment. Angle Orthod., 60(13):199-206, 1990.

Email: libing-1975@163.com

Received: 11-08-2017

Accepted: 17-10-2017 